observations on moths with the use of a mercury vapour light-trap. The fauna of the umbels of cow parsnip (Heracleum sphondylium), the majority of which was insects, is described by R. G. Pearson (Dauntsey's School). R. William Boardman (Bishop's Stortford College) presents a unique ecological study -the cryptogams of a derelict cucumber house. The journal coneludes with reports from member schools and some reviews of natural-history books.

\section{Wheat Breeding in the Near East}

ATtempts to improve cereal production necessarily include a study of host-disease relationships. At the third meeting of the United Nations Food and Agriculture Organization on wheat and barley breeding in the Near East, held recently in Damascus, Dr. T. Abdel-Hak gave an account of work at Giza Experiment Station on the rolative susceptibility of wheat varieties to stem rust, bunt and flag smut, and on the physiological races of stem rust in Egypt, Syria and 'Turkey. Of 236 varieties of wheat produced locally in Egypt or introduced from other countries, fourtecn proved resistant to all three diseases and were thus suitable for future breeding programmes. Resistance to stem rust was less general than to bunt or smut and also varied with the physiological race of rust present, Reliance being the only variety of wheat nearly immune to all the stem rusts so far isolated in Fgypt. Prevalence of the different races might change from one year to another. Tho same race (17) had been predominant in Egypt since 1949 ; but a new one (53) isolated in 1950 had greatiy increased in importance by 1953. Race 17 was also predominant in Syria and Cyprus, whereas in Turkey race 14 occurred most frequently. Although certain races had been isolated in Turkey or Syria which had so far not been found in Egypt, in general there was a great similarity both in the occurrence and prevalence of wheat stem rusts in all the Near East countries. This might indicate uredospore migration, and both further rosearch and co-operation between the various countries in the region are needed to determine the true facts of the case.

\section{Entomology and Public Opinion}

The United States Department of Agriculture has produced an excellent booklet describing the work of professional entomologists. The booklet has been designed particularly to help the layman to understand the part played by 'pure' and 'applied' entomology in his everyday life. Its opening page shows a Dakotan farmer looking at a field of corn which has been devastated by locusts; such incidents happened in the Dakotas in 1932. They have not happened since, and the rest of the booklet, with arresting pictures and prose, describes the reasons. The protection of food from insect pests, the virtual elimination of yellow fevor and malaria, the rare occurrenco of plague, typhus and relapsing fever, protection against clothes moth and other insect pests in the home, are some of the topics used for illustrating the work done by government and other entomologists in the United States. Existing research projects in entomology are also described in a booklet which is to be commended as a means of helping the layman to understand the nature and purpose of science.

\section{Application of the Electrical Potential Analyser}

RESEARCH REPORT No. 22 of the Aluminium Development Association (pp. 24 ; from the Associa- tion, $1953 ; 7 s .6 d$.$) contains a description of an$ electrical potential analyser for the solution of the problem of the determination of the torsion con. stants for bulbs and fillets such as may be used in structural sections. The report is by P. J. Palmer, and the work was part of the investigations sponsored by the Development Association and conducted by Prof. S. C. Redshaw at the University of Birmingham. The solution could have been obtained by the use of the mathematical relaxation method or by the experimental soap-film method; but the clectrical analogy method, which is really the electrical equivalent of the relaxation process, is simple, rapid and accurate and requires little skill in operation. The electrical potential corresponds to the mathematical stress function. After a brief introduction and an outline of the mathematics of the torsion problem, the report describes the analyser and the operation of the apparatus and then gives a series of test results. These are presented in the form of curves and tables and relate to a number of sections including angle fillets, $T$-junction fillets, single- and doublesided bulbs, and sections and fillets with unequal web thicknesses. For one of the test sections a detailed comparison between the rolaxation and analyser solutions is given. The accuracy of the results obtained, about 5 per cent, is discussed, and it is stated that this could be still further improved if a larger number of internal points were used and if the accuracy of the external electrical resistances were higher.

\section{Announcements}

WE regret to announce the following deaths:

Sir Henry Clay, warden during 1944-49 of Nuffield College, Oxford, and president in 1929 of Section F (Economics) of the British Association, on July 30, a.ged seventy-one.

Mr. H. E. Dale, C.B., principal assistant secretary during 1927-35 to the Ministry of Agriculture and Fisheries, author of books on the higher Civil Service in Great Britain, on July 30, aged seventy-eight.

Dr. G. W. A. Dick, of the Medical Research Council, National Institute for Medical Research, London, has been appointed to the chair of bacteriology in The Queen's University of Belfast. 'The following have been appointed lecturers in the University: Colonel D. R. Crone, civil engineering (surveying); and Dr. A. D. E. Pullin, physical chemistry.

THE Association of Agriculture and the Burton Manor Residential College for Adult Education, Burton-in-Wirral, Cheshire, are arranging a course on "Biology and Geography", to be held at the College during August 24-27. One day will be devoted to biological aspects with emphasis on agricultural crops and animal husbandry, and on another the main theme will be geography, in particular the changing pattern of the countryside and the specialized area of dairying districts of Cheshire. There will also be a number of excursions. The course is designed primarily for teachers of rural studies, but should also appeal to all those interested in the countryside. The inclusive fee, including accommodation, is $£ 315 s$. Application forms, to be returned by August 18, can be obtained from the General Secretary, Association of Agriculture, 238-240. Abbey House, 2 Victoria Street, London, S.W.1. 